\title{
A diary study on the causes of English language classroom anxiety
}

\author{
CHRISTINA GKONOU* \\ University of Essex
}

Received: 21 August 2011 Accepted: 21 March 2012

\begin{abstract}
Drawing on learners' diaries, the study reported in this article focused on the English language classroom anxiety (ELCA) of eight Greek EFL learners in private language school settings. The study investigated the extent to which anxiety is amenable to change and the factors contributing to the creation and increase in students' anxiety in class. A training session prior to the commencement of keeping a diary was conducted with the participants under the supervision of the researcher. A total of 64 entries were collected and analysed through qualitative content analysis. The results indicated that students' ELCA fluctuated over time, thus proving that language anxiety is a situation-specific as well as a dynamic variable in L2 contexts. Moreover, a closer scrutiny of the diary data revealed an interplay between linguistic and non-linguistic difficulties substantially affecting learning. Anxiety lay mainly with the participants' perceptions of the input taught, of classroom procedures, and of themselves as learners. Socio-psychological constraints raised by the diarists included fear of negative evaluation by the teacher and by the peers with specific attention to mistakes and correction, and extrinsic motivation. Based on the findings, suggestions are made to improve teacher education and training and to slightly deviate from the exam oriented nature that the Greek educational system imposes on EFL learning.
\end{abstract}

KEYWORDS: anxiety, individual differences, instructed L2 learning, diaries, language skills, negative evaluation, teacher role, classroom research.

\section{RESUMEN}

Este trabajo se centra en el estudio de la ansiedad en la clase de inglés a partir de los diarios de ocho alumnos griegos de inglés como lengua extranjera, en centros privados de enseñanza. El estudio investiga hasta qué punto el grado de ansiedad es susceptible de cambio y los factores que contribuyen a la generación e incremento de ansiedad en clase. Antes de iniciar el trabajo, se organizó una sesión de entrenamiento con los participantes, a cargo del investigador. Se recogieron 64 muestras, que fueron analizadas mediante análisis cualitativo. Los resultados pusieron de manifiesto que el grado de ansiedad de los alumnos fluctuaba a lo largo del tiempo, demostrando así que la ansiedad está relacionada con la situación y constituye una variable en el contexto de aprendizaje/enseñanza de una lengua extranjera. Además, un análisis más detallado de los diarios recogidos muestra que existe relación entre los problemas lingüísticos y no lingüísticos del aprendizaje. La ansiedad depende sobre todo de la percepción de los alumnos sobre el input que reciben, de las actividades de la clase y de ellos mismos como aprendices. Los diarios también implican restricciones socio-sicológicas, como miedo a la evaluación negativa, por alumnos y profesor, con énfasis en los errores y en la corrección y la motivación extrínseca. A partir de los resultados, se formulan algunas sugerencias para mejorar la formación de profesores y poner menor énfasis en el examen, característica del sistema educativo griego en el entorno de enseñanza del inglés como lengua extranjera.

PALABRAS CLAVE: Ansiedad, diferencias individuales, diarios de clase, destrezas lingüísticas, evaluación negativa, función del profesor, investigación en el aula.

*Address for correspondence: University of Essex, Department of Language \& Linguistics, Wivenhoe Park, CO4 3SQ, Colchester, United Kingdom. E-mail: cgkono@essex.ac.uk 


\section{INTRODUCTION}

Second language acquisition research has long been exploring the role that individual differences play on the differential success among L2 learners (Dörnyei, 2005; Skehan, 1989). As the term suggests, individuals differ from each other with reference to specific characteristics (Dörnyei, 2005). Anxiety seems to have its own place on the individual differences taxonomy manifesting itself as a major source of student inconvenience in class and causing further feelings of distress and fear. The definition of foreign language classroom anxiety (FLCA) provided by Horwitz, Horwitz, and Cope (1986) presents a clear depiction of the notion of this type of negative affect. Being conceptualized as "a distinct complex of selfperceptions, beliefs, feelings, and behaviors related to classroom language learning arising from the uniqueness of the language learning process” (Horwitz et al., 1986: 128), it presents itself as a unique type of anxiety specific to language learning (MacIntyre \& Gardner 1989, 1991) and constitutes one aspect of the bipartite approach to identifying FLCA. Horwitz and Young (1991) also viewed FLCA as a transfer of anxiety from other domains, such as test anxiety or even stage fright. In their investigation into FLCA, Horwitz et al. (1986) had indeed selected communication apprehension, fear of negative evaluation, and test anxiety as three anxiety types closely related to the major construct of FLCA.

The question, however, remains: how far can we talk about successful language learning with anxious language learners? According to MacIntyre (1999), "even if one views language anxiety as being a unique form of anxiety, specific to second language contexts, it is still instructive to explore the links between it and the rest of the anxiety literature” (p. 28). While anxiety can be thought of as stemming from the learners, the literature sees it as a multifaceted and dynamic variable being influenced by and influencing a range of individual differences variables, such as self-confidence (Gardner et al., 1997; MacIntyre et al., 1997) and self-esteem (Onwuegbuzie, Bailey, \& Daley, 1999; Price, 1991), as well as classroom constructs, including performance and achievement (Aida, 1994; Horwitz, 2001; Saito \& Samimy, 1996), and the teacher (Aida, 1994; Oxford, 1999; Young, 1991). Hence, it is vital to determine the interrelatedness between the English language learner, the English language classroom, and the nature of anxiety in order to detect its causes and create more secure language learning environments in the long run.

\subsection{Setting a theoretical framework: the major stressors}

A starting point for discussing those forces inducing anxiety in EFL learning is the situationspecific character commonly associated with language anxiety in the literature (Ellis, 2008; Horwitz et al., 1986; MacIntyre, 1999). MacIntyre (1999) argues that in classroom-oriented contexts anxiety is stable over time but inconsistent across situations. An individual may be nervous in taking a test but not in speaking in class. Given that contexts differ, the level of 
student reaction in class and the amount of interference between anxiety and performance differs as well.

Individual learner characteristics have an enormous impact on language anxiety. Learners can worry over and be highly vulnerable in performing in front of their peers. Bailey (1983) analysed the diary entries of eleven students and attributed their anxiety to competitiveness among them as well as a tendency to compare themselves with their classmates on the basis of their self-perceived proficiency level. Tsui (1996) reported students' fear of mistakes and of facing derision by peers as the principal cause of English language classroom reticence. Over concern about others' opinion has been catalogued not only as a feature of anxious language learners but of perfectionists as well. Gregersen and Horwitz (2002) found that both anxious language learners and perfectionists are worried over the opinions of others and tend "to fear the evaluation of their peers and the subsequent possibility of appearing foolish” (p. 567). In addition to fear of evaluation, their research also demonstrated that “anxious students not only noticed errors but lamented them” (Gregersen \& Horwitz, 2002: 567).

The above arguments conclusively establish a relationship between the foreign language and the student reactions to specific language classroom events, like committing errors. English language learners are expected to perform - and quite often successfully - in a language that they have not yet adequately or fully mastered. Horwitz et al. (1986) and Horwitz (2001) argued that FLCA stems from learners' difficulties to adapt to the new language. In particular, “as an individual's communication attempts will be evaluated according to uncertain or even unknown linguistic and socio-cultural standards, second language communication entails risk-taking and is necessarily problematic" (Horwitz et al., 1986: 128). Young (1990) claimed however that the problem does not arise when students have to use English, but when they have to use it in front of others either in the form of speaking or even when writing their work on the board.

Young's (1990) theory had in fact corroborated Horwitz et al.'s (1986) model of FLCA being related to communication apprehension and fear of negative evaluation (Horwitz, 2010). According to McCroskey (1978), communication apprehension is "an individual's level of fear or anxiety associated with either real or anticipated oral communication with another person and persons” (p. 78). What Watson and Friend (1969) had labeled fear of negative evaluation was also interpreted as relating to anxiety within the learner. Fear of negative evaluation was defined as "apprehension about others' evaluations, avoidance of evaluative situations, and the expectation that others would evaluate oneself negatively" (Watson \& Friend, 1969: 449). More recent research conducted by Dörnyei (2001) also asserted that language classrooms are "inherently face threatening environments" where learners are expected to perform through the use of a "severely restricted language code" (p. 91). Culturally and sociolinguistically speaking, Jones (2004) proposed that culture is a causal 
factor in language anxiety, given that "a concept of face exists, doubtless, in every society and plays a part in inhibiting interaction for vast numbers of people whose grasp of a foreign language is imperfect” (p. 35). Hence, the potential loss of face in class in conjunction with low performance and problematic output often cater for an increase in students' anxiety.

Communication apprehension and fear of negative evaluation are therefore seen not only as connected with but also as resulting in English language classroom speaking anxiety. Looking at anxiety as a consequence of the four skills, speaking has received the most empirical attention in the existing body of literature so far (Burden, 2004; Hilleson, 1996; Phillips, 1991, 1992; Woodrow, 2006; Young, 1990; Young, 1992). Anxiety largely determines how well students perform in oral activities and this effect is presumably due to the nature of speaking itself being more public and ego involving than the other skills. Kitano (2001) found a significant negative correlation between anxiety and self-ratings of perceived speaking ability, and concluded that being assigned a social perspective, speaking constitutes the primary skill to be contrasted with that of peers, teachers, and native speakers. In a comparative study of anxiety between a reading course and a conversation course, Kim (2009) found that students were more anxious in conversation classes owing to having to speak in front of others and to the high speaking requirements set by the course. In examining the relationship between anxiety and speaking, one can deduce that on the whole speaking anxiety is subsumed under the umbrella term of language classroom anxiety. Nevertheless, the impact of anxiety on the remaining three skills offers a different perspective on this relationship.

Horwitz, Zallon, and Luo (2010) classify listening as the most-anxiety provoking skill after speaking. In an investigation into listening anxiety in the Arabic language classroom, Elkhafaifi (2005) found that foreign language learning anxiety and listening anxiety are related to but distinguishable from each other. Listening anxiety originates from the level of difficulty or unfamiliarity of the listening texts and tasks. If the input is complicated, unclear, or quick, listening anxiety heightens, because, given that students have been instilled with unrealistic beliefs about second or foreign language listening, they feel that they must understand every word heard (Oxford, 1993; Vogely, 1998, 1999).

Although anxiety accompanying writing tasks could be potentially considered one of the most innocuous types of anxiety due to the more ample time allowed to the students to reflect, choose, and revise compared to speaking, it seems that a big number of students experience some kind of “writer’s block” while practicing this skill (Leki, 1999: 65). Cheng, Horwitz, and Schallert (1999) concluded that there is a language-skill-specific-anxiety affecting second language writing, and thus writing anxiety should be differentiated from classroom anxiety. Ozturk and Cecen (2007) claimed that, despite the amount of input, difficulties with the L2, such as vocabulary, spelling, morphology, and syntax, as well as 
writing anxiety could lead to the production of "low quality" output from the students as a result of classroom practices.

Finally, based on their hypothesis that certain language learners experience reading anxiety, Saito, Horwitz, and Garza (1999) found that their participants were more anxious in terms of reading than in terms of general FLCA. As was the case with second language writing anxiety, Saito et al. (1999) distinguished reading anxiety from foreign language anxiety and emphasized that cultural knowledge plays a pivotal role in foreign language reading and could reduce students' anxiety in that domain. To be more specific, Saito et al. (1999) argued that "anxiety is also anticipated when a reader can decipher the words of a foreign language text, but not its sense, because of incomplete knowledge of the cultural material underlying the text” (p. 203). In a factor analytic study, Matsuda and Gobel (2001) found that foreign language reading anxiety was closely related to FLCA, giving evidence that classroom anxiety caused by reading is due to deficient reading study skills.

Outside of the learner, an integral part of classroom lessons constitutes the teacher, who inadvertently arouses anxiety in the students in a variety of ways. A condescending and judgmental teacher attitude has been reported as one of the most salient causes of anxiety (Aida, 1994; Samimy, 1994). Furthermore, inappropriate error correction techniques and harsh criticism of errors committed in the course of a lesson proved to be disheartening for the students and raised the amount of fear of negative evaluation by the instructor (Kitano, 2001; Young, 1990). "Style wars" or "style conflicts", that is a mismatch between a student's learning style and a teacher's teaching style, have also been listed among the teachergenerated sources of anxiety (Oxford, 1999: 217).

\section{METHOD}

\subsection{The study}

The two research questions that guided the current study are as follows:

1. To what extent is ELCA subject to change throughout a sequence of lessons?

2. What are the principal causes of ELCA?

\subsection{Participants}

Eight adult students enrolled in lower intermediate to upper advanced EFL classes at three private language schools in Greece consented to participating in this diary study. The informants were pooled from an initial group of 128 students having participated in the quantitative phase of this research, where they were asked to take the Foreign Language Classroom Anxiety Scale (FLCAS), a 33-item Likert-type instrument of measuring anxiety 
specific to language learning (Horwitz et al., 1986). In this study, the term 'foreign language' used in the original FLCAS was replaced with 'English language'. On the basis of a scale from one to five ("strongly disagree" to "strongly agree"), the students assessed their degree of anxiety with relation to fear of negative evaluation ("I keep thinking that the other students are better at English than I am"), fear of failure ("I worry about the consequences of failing my English language class"), speaking anxiety ("I never feel quite sure of myself when I am speaking in my English language class”), teacher-generated anxiety ("I get nervous when I don't understand every word the English teacher says”), and comfortableness in taking English classes (“I don't understand why some people get so upset over English language classes”).

The anxiety score was derived by summing the students' ratings of all 33 items. Reversed scores were given to negatively worded items so that a high score represented high anxiety in the English classroom. Possible scores ranged from 33 to 165 . The mean score was 74.8 with a standard deviation of 16.5. Based on the scores of this instrument, nineteen students were invited to proceed to the diary study. Eight students ultimately provided the researcher with complete diaries. The FLCAS scores of the eight individuals in the study are listed in Table 1. Seven out of the eight participants were female, and all ranged in age from 18 to 35.

\begin{tabular}{ll}
\hline Participant & FLCAS score \\
\hline Student 1 & 98 \\
Student 2 & 90 \\
Student 3 & 104 \\
Student 4 & 94 \\
Student 5 & 92 \\
Student 6 & 95 \\
Student 7 & 108 \\
\hline Student 8 & 100 \\
\hline
\end{tabular}

Table 1. FLCAS scores of the participants

\subsection{Instruments: learner diaries}

The most comprehensive definition of a diary study has been given by Bailey (1990): “a diary study is a first-person account of a language learning or teaching experience, documented through regular, candid entries in a personal journal and then analysed for recurring patterns or salient events” (p. 215). Diaries as classroom oriented research tools are not without their faults though. Catering for both introspection and retrospection from the part of the learners (McDonough \& McDonough, 1997), diary data are occasionally subject to memory gaps from 
the part of the diarists. As Fry (1988) points out, "with retrospective data, all the problems of cognition in introspective data are magnified by the lapse of time between the event and the reporting of it” (p. 160). Issues of data reduction and reliability of categorization and coding have also been listed among the drawbacks of diary studies (Bailey, 1991). Still, diaries are valuable in second language acquisition research. They account for "the unexplored processes of classroom language learning”, or, to quote Long (1983), they provide data from "inside the black box". Diaries give researchers the opportunity to study each learner's views on affective factors, such as sources of stress in second language learning, in an unobtrusive way (Bailey \& Oschner, 1983; Bailey, 1991; Dörnyei, 2007). Bailey (1991) strongly argues that

diary studies are absolutely essential to advancing our understanding of classroom language learning. At the present time we are working with an unrefined tool to craft an only dimly understood representation of language learning. Properly done, the diary studies can provide us with important missing pieces in this incredibly complex mosaic pieces which may not be fully accessible by any other means ... An appreciation for individual differences ... leads directly to the importance of studying single learners in depth (pp. 87-88).

Learner diaries were therefore selected as a means of following up the students' responses to the questionnaire. The researcher looked at those entries with insights into the causes of ELCA that further delved into and justified the quantitative results.

64 entries were gathered in total. All eight participants reported on their experiences in their diaries once a week for a period of eight weeks. An event-contingent design was adopted in which the participants were required to provide an entry each time a lesson occurred (Dörnyei, 2007). The study took place between January and March 2011 for the purposes of avoiding beginning and end-of-year procedures, like adjusting to the new class or receiving transcripts of records, that by definition involve some amount of stress built in and might influence the originality and purposefulness of the study. The diarists were instructed to record activities that were anxiety provoking for them, and to clarify or expand on the issues raised. The diary entries were received either weekly or fortnightly.

Focal points for keeping the diary were the following:

- the most and least anxiety-provoking aspects of the lesson

- the level of anxiety experienced when dealing with the four skills

- the symptoms of anxiety the learners were faced with

- the coping strategies deployed by both teachers and students, and

- the students' thoughts regarding their teacher and their peers. 


\subsection{Data analysis}

The primary method of investigating the experiences of students with reference to their anxiety was qualitative content analysis. Berg (2007) defines it as "a careful, detailed, systematic examination and interpretation of a particular body of material in an effort to identify patterns, themes, biases, and meanings” (pp. 303-304). In a nutshell, content analysis constitutes a means of reducing, simplifying, and interpreting the data through systematic qualitative coding techniques. According to Dörnyei (2007), qualitative content analysis is often being referred to as "latent-level analysis" (p. 246), since it focuses on a second-level interpretation of the deeper meaning of the data.

Initial coding followed by second-level coding were applied to the analysis of the learner diaries. The researcher started by skimming through all the diaries to obtain a general idea of the data, and then scanned the texts to identify any passages relevant to the topic. Codes were assigned to each specific passage, and similar categories were clustered together under one general code. These variables were also counted in order to produce a hierarchical sequence of all labels.

\section{RESULTS}

\subsection{ELCA and change}

The first research question concerned the degree of ELCA being subject to change throughout a sequence of eight lessons investigated by means of learner diaries. As seen in table 2 below, Greek EFL students’ ELCA has not remained constant over time ${ }^{1}$.

\begin{tabular}{lcccccccc}
\hline & Week & Week & Week & Week & Week & Week & Week & Week \\
& $\mathbf{1}$ & $\mathbf{2}$ & $\mathbf{3}$ & $\mathbf{4}$ & $\mathbf{5}$ & $\mathbf{6}$ & $\mathbf{7}$ & $\mathbf{8}$ \\
\hline Student 1 & - & + & + & + & + & + & + & - \\
Student 2 & + & + & + & - & + & - & - & + \\
Student 3 & + & - & - & - & - & - & - & + \\
Student 4 & - & + & + & + & + & - & - & + \\
Student 5 & + & - & + & - & - & + & + & - \\
Student 6 & - & - & + & - & - & + & + & - \\
Student 7 & + & - & - & + & - & + & - & - \\
\hline Student 8 & + & + & + & + & + & - & + & + \\
\hline
\end{tabular}

Table 2. Students’ ELCA change over a period of eight weeks 
The above table reveals that Greek EFL learners' ELCA fluctuated throughout the course, thus justifying the situation-specific character attributed to language anxiety. The reasons for anxiety change are listed in the following section.

\subsection{The major stressors}

The second research question sought to capture the causes of ELCA of Greek EFL learners. According to the findings, linguistic factors as well as socio-psychological barriers combined to induce anxiety within the learners.

\subsubsection{Input and low self-efficacy}

One of the most anxiety-provoking factors influencing the learning experience was input, and specifically, the level of difficulty of the English language taught in class and the extent to which input was comprehensible by the learners. Participants in this study expressed concerns about input in that they believed that the complexity of both grammar and vocabulary could increase their ELCA and decrease their own perceptions of self-efficacy. The following extracts were typical in illustrating that point ${ }^{2}$ :

\section{Extract 1:}

I am afraid of the grammar and the vocabulary and it's true that the English language is very complicated. One word can mean many things. For example, minutes means the minutes of the hour, but also the records of the meeting. Couldn't English people find another word? I hope that I'll manage to remember all the details when I'll have to speak or to write.

\section{Extract 2:}

Phrasal verbs are another complicated chapter of English grammar. How easy is it to keep so many things in mind? To speak English with so many rules and exceptions in mind? I tried to keep calm.

These comments imply that there exists a strong interplay between input, anxiety, and self-efficacy. In social cognitive theory, self-efficacy takes on exaggerated importance in the arousal of student anxiety (Bandura, 1986, 1997). Individuals are capable of assessing the level of success of their actions needed for achievement through an inventory of efficacy beliefs that they possess. Given that anxiety emanates from the confidence and efficacy students express when involved in classroom activities, a weakened sense of both psychological and cognitive constructs negatively interferes with anxiety and ultimately achievement. 


\title{
3.2.2. The four skills
}

Learners in this diary study experienced ELCA as a result of speaking and listening mostly. Some of the negative connotations the former skill was associated with include crying, difficulties in producing oral output, and fear of facing derision by the peers in class:

\begin{abstract}
Extract 3:
Yesterday we were talking in the class about theatre and when it was my turn to tell my opinion, I was blocked. I have a problem in saying something, I feel that I should have plenty of time so as to think and to organize my thoughts, to choose the correct words, and finally to express my opinion. Although our teacher is talking to us in English, I almost always answer in Greek. What I need, obviously, is to try harder. How much better things would be without the speaking.

Extract 4:

I don't know why but this period of time I feel a little bit sad about English. I think that this caused because I feel anxious when I speak in class. I love speaking but I can't speak in front of all those people. I forget what I want to say and I make mistakes. I hope this will change. I am so nervous I have to relax and slow down otherwise I will start crying.
\end{abstract}

The above entries reveal both the internal and the extrinsic aspect of speaking anxiety. Speaking anxiety is presented as a learner trait impeding a learner's efforts to practice and develop oral skills. At the same time, factors other than the learner provoke debilitating anxiety when speaking in class. The presence of the teacher and the peers evokes a sentiment of fear of self-exposure and of being the centre of attention in front of others. Irrespective of positive attitudes towards speaking expressed by the second informant, the classroom environment seems to largely affect anxiety regarding speaking.

Listening was reported as the second most anxiety-ensuing skill. The primary reason for that was skilfully summarized as follows:

\section{Extract 5:}

Listening is the part which makes me feel anxious because it's something that you hear it or not, there's no second chance.

Hence, the classroom-oriented inauthentic practice of EFL listening trains learners to listen merely for the purposes of getting the right answer, which, psycholinguistically speaking, has an impact on the ELCA originating from listening.

As far as writing anxiety is concerned, in-class writing activities maximize students' English language classroom writing anxiety primarily due to the time limits set by the teacher. The following extract further delineates this source of writing anxiety:

\section{Extract 6:}

The big surprise came when we were told that we were going to do a writing in class. No one was happy about that and everyone started complaining. I got very angry and anxious because we only had half an hour to finish it. I actually got so anxious that I didn’t know 
what to write and wrote about half a page, maybe a little more. I wish we hadn't done that writing task or our teacher could have at least warned us about it.

Unfamiliarity of the topic or lack of ideas was also reported as engendering writing anxiety among EFL learners.

\begin{abstract}
Extract 7:
We then talked about film review writing and got one for homework. We all got a bit stressed though because we had to write about an old film and no one really knew many old films.

In addition to time constraints and lack of ideas, writing anxiety also has its roots in mistakes over writing activities and on the strategies employed by the teachers to correct them.

Extract 8:

I said earlier I prefer writing to speaking but writing has its own difficulties: mistakes are apparent, mistakes are there ready to be corrected by the teacher and then you have a piece of paper full of crosses and corrections. This is anxiety provoking!
\end{abstract}

Finally, reading anxiety was primarily input-driven and skill-specific. Students were dissatisfied with their experience while reading and considered those lessons stressful due to the difficulty of the reading passage and the amount of unknown lexis.

\title{
Extract 9:
}

I really worry about reading and it drives me crazy. Today's English lesson was stressful due to the reading paper we had to do. It was very difficult. So many words I can't understand. I have to improve if I want to succeed.

\subsubsection{The mistakes and the teacher}

The diary entries revealed an overall student tendency to be intimidated by and disappointed at the mistakes they make in class. This over-concern, however, was unrelated to any fear of appearing foolish in front of their teacher and their peers. On the contrary, the number and type of mistakes had considerable impact on the students' beliefs about their own progress and performance in class. Knowing in advance that they would give an incorrect answer increased their level of anxiety and engendered a personal feeling of low self-efficacy and expected fear of failure:

\section{Extract 10:}

The grammar looked very simple but I made many mistakes which were so stupid! I was disappointed...again.

Nevertheless, the participants in this study did not express any dissatisfaction with reference to the way their teachers treated their mistakes. Teacher-generated anxiety was merely attributed to the teacher attitude towards unexpectedly low student performance: 


\begin{abstract}
Extract 11:
Today I didn't remember some of the words and my teacher was looking at me strictly. She talked to me and said that I was not well prepared and that I must organize my study better. I was disappointed and sad because my teacher can't understand how difficult it is for me to study English again. During these three years that I had stopped my English lessons, I have forgotten many things. Many times I feel this anxiety and pressure by the teacher and this is not a good feeling at all!
\end{abstract}

\title{
3.2.4. Extrinsic motivation
}

In their self-determination theory, Deci and Ryan (1985) distinguished between two types of orientation of motivation on the basis of the reasons why students are learning English. Hence, motivation can either be intrinsic referring to learning a language for its own sake, or extrinsic occurring when there is an external reward leading to a separable outcome. Dörnyei (2005) claimed that the intrinsic and extrinsic motives to learn proved that learners who studied a language on their own free will (intrinsically motivated learners) were those who managed to increase their linguistic competence and become autonomous as opposed to those who learned a language because they had to (extrinsically motivated learners).

Extrinsic motivation was found to act as a debilitating element that caused anxiety in the English language classroom. The following extract elucidates this interrelatedness:

\footnotetext{
Extract 12:

My teacher says that I'm good in reading comprehension. Vocabulary needs studying, listening needs attention, writing needs concentration, speaking needs courage, grammar needs practice... I need the certificate for my job. I'm not complaining, I don't mind studying, it's just this feeling of anxiety that I've felt so many times in my life, and I feel it again. On the other hand, trying and learning is more creative than being anxious. So I must relax and concentrate on my duty.
}

The extract reveals that being conscious of the fact that an external reward might emerge through studying and succeeding increases the levels of ELCA. As a consequence, a positive correlation exists between anxiety and extrinsic motivation. Intrinsic motivation, however, led participants to opposite directions.

\section{Extract 13:}

I can't wait till the next lesson to continue the unit on emphasis. I want to learn more.

Willingness to integrate into the foreign language community and enrich the knowledge about it was therefore negatively correlated with classroom anxiety.

\subsubsection{Marks}

High reliance on marks constituted another factor inducing anxiety in the English language classroom. The students admitted that receiving a good mark was a relief to them. Further, the 
data provided evidence that the mark rather than the activity is of primary concern to the learners:

\section{Extract 14:}

The exercise felt a bit easier than I'd expected it to be. But the results still stress me.

\subsubsection{Tests}

According to Sieber (1980), "test anxiety is usually defined as a set of responses to a class of stimuli that have been associated in the individual's experience of evaluation or testing” (p. 18). A cognitive view of test anxiety has been adopted by the Greek EFL learners in this study. Through cognition, individuals appraise tests and identify the evaluative stressors (Sarason, 1980). Students are anxious about their perceptions of tests rather than the actual testing situation and, as a result, tests become a noxious experience for them:

\section{Extract 15:}

Today's lesson was quite stressful...I have to say that the idea of the test was more stressful than the test itself. Knowing that I will write a test freaks me out a little.

\section{DISCUSSION}

Greek EFL learners' points of view raise a number of questions and pedagogical implications to be considered by both EFL teachers and researchers. The participants' emphasis on the difficulty of input presented to them in class lay on their negative self-related cognition of being incapable of storing it in mind and consequently producing it successfully in the form of output. It is dubious, therefore, whether comprehensible input can cater for comprehensible output. It seems that the input hypothesis interferes with the affective filter hypothesis, thus corroborating Krashen's (1985) suggested monitor model: “the affective filter hypothesis implies that our pedagogical goals should not only include supplying comprehensible input, but also creating a situation that encourages a low filter” (p. 32). Questioning the nature and functions of comprehensible output, Krashen (1998) further claims that the comprehensible output hypothesis, which suggests that second language acquisition is achieved when individuals are pushed to speak, entails a degree of discomfort in itself granted that speaking constitutes one of the greatest sources of anxiety. Hence, taking into account that pushed output is uncomfortable for the learners, there should be a balance between the type of input supplied in instructed language learning settings and the teachers' expectations of students' output.

As far as skills-induced anxiety is concerned, at first glance it presents itself as a skills-specific anxiety generated by the nature of the skills themselves and by an inherent 
degree of difficulty associated with each skill. It seems, however, that what really influences the students' in-class negative affect is the pedagogy underlying the teaching of skills, and more specifically, the teaching of listening and writing. During listening practice, the learners' focus is shifted to listening in order to get the right answer, receive a high mark, and occasionally be better than the rest of the class. Nevertheless, "when teachers and students make the shift from listening for correctness or listening to understand word for word, to listening for a message, the motivation to understand increases and the fear of being "wrong" decreases" (Vogely, 1999: 119).

Additionally, listening principles should include among others a certain level of authenticity that will enable students to realize the what and the why in listening comprehension tasks. Firstly, classroom listening should resemble everyday life listening by clearly helping learners discern what they are listening for and activating prior knowledge and relevant schemata. Second, as Harmer (2007) highlights, "any listening material is also useful for studying language use and a range of pronunciation issues” (p. 136). Thus, EFL teachers should first ascertain that the students are engaged with the topic of the listening as well as the listening task and that they really want to listen, and then proceed to listening practice for the sake of learning.

Writing in-class practice, as this occurs in EFL classrooms in Greece, adheres to the principles of writing-for-writing: "whereas in writing-for-learning activities it is usually the language itself that is the main focus of attention, in writing-for-writing we look the whole text. This will include not just appropriate language use, but also text construction, layout, style, and effectiveness" (Harmer, 2007: 112). The students' comments in their diaries point out that it is product rather than process writing that causes writing anxiety due to the time constraints set by the instructors. Taking into account the exam-oriented nature of the Greek educational system and the fact that teaching English in Greece basically means teaching for the examinations of Cambridge, Michigan, and the national English examination, one can deduce that the time limits are given by the teachers in an attempt to put into practice writing as an exam skill. Therefore, for the purposes of minimizing writing anxiety, teachers and students should realize that writing is not an innate skill or capacity and there is a long way until students are able to produce good quality texts. Moreover, similarly to listening, it is essential that teachers construct real-life, purposeful writing activities, since students develop when they carry out activities that are meaningful to them. In all cases, writing and listening should be viewed as a goal without repudiating the focus on grammatical and lexical accuracy as well as on pronunciation and intonation respectively.

With reference to speaking the findings of the current study corroborate Young's (1990) and Dörnyei's (2001) research and clearly show that, being a social as well as trait anxiety, speaking anxiety constitutes a face-threatening condition which detracts learners from speaking practice. The fear of making mistakes in the presence of the teacher and the peers as 
well as the thought that by speaking one automatically becomes the object of comparison in a classroom context increase the levels of anxiety with relation to this skill. Overt error correction or harsh criticism over students' oral output may contribute to speaking anxiety. Thus, positive reinforcement, praise, and the belief that mistakes are a sign that the students are doing a learning process should be provided to the students. In addition, correcting mistakes unobtrusively in the form of recasts, that is "targetlike reformulations of the errors that learners commit in the course of communicative activities” (Sheen, 2008: 837), constitutes an appropriate anxiety-free teacher intervention during speaking activities.

A final point to be raised is the interrelatedness between individual differences in the present study. Anxiety works in tandem with low self-confidence and low self-efficacy and imposes on learners to underestimate their learning capacities and their potential contributions to the classroom community. Extrinsic motivation also heightens students' ELCA, thus calling for a positive correlation between motivation and anxiety. As motivation increases, student anxiety increases as well. The results, however, are indicative of the fact that learners are relaxed when they are intrinsically motivated; their eagerness to integrate into the English language community and learn more about the target language and culture accounts for pleasant and comfortable EFL lessons.

\section{CONCLUSIONS}

This study constituted an attempt to identify the major stressors catering for ELCA. The results revealed that input, language skills, the teacher, mistakes made in class, high reliance on marks, tests, and extrinsic motivation constitute the causes of anxiety.

Horwitz et al. (1986) have made a strong case for the role played by speaking, the teacher, and the peers, in the creation of FLCA. More recent studies suggest that the remaining skills also contribute to negative affect in class (Cheng, Horwitz, and Schallert, 1999; Horwitz, Zallon, and Luo, 2010). The current study contributes to this line of research by discerning some further causes of anxiety in the Greek EFL context. To date, relatively few studies have examined sources of anxiety other than the four skills. What is more, the number of diary studies investigating anxiety factors in instructed English language learning contexts is even smaller. This study suggests that much is to be gained by directing at causes of EFL anxiety for the purposes of exploring ways to assist learners reduce and, finally, overcome their anxiety in class.

Future research could be orientated towards a more thorough investigation of the way individual difference factors intertwine with anxiety by including correlation studies among instruments operationalising the individual differences referred to above. Additionally, the 
composite effect of classroom anxiety and test anxiety could be addressed in order to determine the extent to which testing situations affect general classroom performance anxiety.

\section{NOTES}

1. The pluses (+) signify that a student was anxious in that lesson. Accordingly, the minuses (-) show that students were not anxious at all in those lessons.

2. Diary extracts are kept in the original.

\section{REFERENCES}

Aida, Y. (1994). Examination of Horwitz, Horwitz, and Cope's construct of foreign language anxiety: the case of students of Japanese. The Modern Language Journal, 78, 155-168.

Bailey, K. M. (1983). Competitiveness and anxiety in second language learning: looking at and through the diary studies. In H. W. Seliger \& M. H. Long (Eds.), Classroom-oriented research in second language acquisition (pp. 67-103). Rowley, MA: Newbury House.

Bailey, K. M. (1990). The use of diary studies in teacher education programs. In J. C. Richards \& D. Nunan (Eds.), Second language teacher education (pp. 215-226). Cambridge: Cambridge University Press.

Bailey, K. M. (1991). Diary studies of classroom language learning: the doubting game and the believing game. In E. Sadtono (Ed.), Language acquisition and the second/foreign language classroom (pp. 60-102). Singapore: SEAMEO Regional Language Centre.

Bailey, K. M., \& Oschner, R. (1983). A methodological review of the diary studies: windmill tilting or social science? In K. M. Bailey, M. H. Long, \& S. Peck (Eds.), Second language acquisition studies (pp. 188-198). Rowley, MA: Newbury House Publishers.

Bandura, A. (1986). Social foundations of thought and action: a social cognitive theory. Englewood Cliffs, NJ: Prentice Hall.

Bandura, A. (1997). Self-efficacy: the exercise of control. New York: W. H. Freeman.

Burden, P. (2004) The teacher as facilitator: reducing anxiety in the EFL university classroom. JALT Hokkaido Journal. 8, 3-18.

Cheng, Y., Horwitz, E. K., \& Schallert, D. L. (1999) Language anxiety: differentiating writing and speaking components. Language Learning, 49(3), 417-446.

Berg, B. L. (2007). Qualitative research methods for the social sciences. ( $6^{\text {th }}$ ed.). Boston: Pearson.

Deci, E. L., \& Ryan, R. M. (1985). Intrinsic motivation and self-determination in human behavior. New York: Plenum.

Dörnyei, Z. (2001). Motivational strategies in the language classroom. Cambridge: Cambridge University Press.

Dörnyei, Z. (2005). The psychology of the language learner: individual differences in second language acquisition. Mahwah, NJ: Lawrence Erlbaum Associates.

Dörnyei, Z. (2007). Research methods in applied linguistics: quantitative, qualitative, and mixed methodologies. Oxford: Oxford University Press.

Elkhafaifi, H. (2005). Listening comprehension and anxiety in the Arabic language classroom. The Modern Language Journal, 89(2), 206-220.

Ellis, R. (2008). The study of second language acquisition. ( $2^{\text {nd }}$ ed.). Oxford: Oxford University Press.

Fry, J. (1988) Diary studies in classroom SLA research: problems and prospects. JALT Journal, 9 (2), 158-167.

Gardner, R. C., Tremblay, P. F., \& Masgoret, A. (1997) Towards a full model of second language learning: an empirical investigation. The Modern Language Journal, 81, 344-362. 
Gregersen, T. \& Horwitz, E. K. (2002). Language learning and perfectionism: anxious and nonanxious language learners' reactions to their own oral performance. The Modern Language Journal, 86(4), 562-570.

Harmer, J. (2007). How to teach English. Harlow, Essex: Pearson Longman.

Hilleson, M. (1996) "I want to talk with them, but I don't want them to hear”: an introspective study of second language anxiety in an English-medium school. In K. M. Bailey \& D. Nunan (Eds.), Voices from the language classroom: qualitative research in second language education (pp. 248-277). Cambridge: Cambridge University Press.

Horwitz, E. K. (2001). Language anxiety and achievement. Annual Review of Applied Linguistics, 21, 112-126.

Horwitz, E. K. (2010) Research timeline: foreign and second language anxiety. Language Teaching, 43 (2), 154-167.

Horwitz, E. K., Horwitz, M. B., \& Cope, J. (1986). Foreign language classroom anxiety. The Modern Language Journal, 70, 125-132.

Horwitz, E. K., \& Young, D. J. (1991). Language anxiety: from theory and research to classroom implications. Englewood Cliffs, NJ: Prentice Hall.

Horwitz, E. K., Tallon, M., \& Luo, H. (2010). Foreign language anxiety. In J. C. Cassady (Ed.), Anxiety in schools: the causes, consequences, and solutions for academic anxieties (pp. 95115). New York: Peter Lang Publishing.

Jones, J. F. (2004) A cultural context for language anxiety. English Australia, 21 (2), 30-39.

Kim, S. Y. (2009). Questioning the stability of foreign language classroom anxiety and motivation across different classroom contexts. Foreign Language Annals, 42(1), 138-157.

Kitano, K. (2001). Anxiety in the college Japanese language classroom. The Modern Language Journal, 85(4), 549-566.

Krashen, S. (1985). Principles and practice in second language acquisition. Oxford, NY: Pergamon.

Krashen, S. (1998). Comprehensible output? System, 26, 175-182.

Leki, I. (1999). Techniques for reducing second language writing anxiety. In D. J. Young (Ed.), Affect in foreign language and second language learning: a practical guide to creating a low-anxiety classroom atmosphere (pp. 64-88). Boston: McGraw Hill.

Long, M. H. (1983). Inside the "black box": methodological issues in classroom research on language learning. In W. H. Seliger \& M. H. Long (Eds.), Classroom oriented research in second language acquisition (pp. 3-35). Rowley, MA: Newbury House Publishers.

MacIntyre, P. D. (1999). Language anxiety: a review of the research for language teachers. In D. J. Young (Ed.), Affect in foreign language and second language learning: a practical guide to creating a low-anxiety classroom atmosphere (pp. 24-45). Boston: McGraw Hill.

MacIntyre, P. D., \& Gardner, R. C. (1989) Anxiety and second language learning: toward a theoretical clarification. Language Learning, 39, 251-275.

MacIntyre, P. D., \& Gardner, R. C. (1991) Language anxiety: its relation to other anxieties and to processing in native and second languages. Language Learning, 41, 513-534.

MacIntyre, P. D., Noels, K. A., \& Clement, R. (1997) Biases in self-ratings of second language proficiency: the role of language anxiety. Language Learning, 47, 265-287.

Matsuda, S., \& Gobel, P. (2001) Quiet apprehension: reading and classroom anxieties. JALT Journal, 23, 227-247.

McCroskey, J. C. (1977) Oral communication apprehension: a summary of recent theory and research. Human Communication Research, 4, 78-96.

McDonough, J., \& McDonough, S. (1997). Research methods for English language teachers. London: Arnold.

Onwuegbuzie, A. J., Bailey, P., \& Daley, C. E. (1999) Factors associated with foreign language anxiety. Applied Psycholinguistics, 20, 217-239.

Oxford, R. (1993). Research update on teaching L2 listening. System, 21(2), 205-211.

Oxford, R. (1999). "Style wars" as a source of anxiety in language classrooms. In D. J. Young (Ed.), Affect in foreign language and second language learning: a practical guide to creating a lowanxiety classroom atmosphere (pp. 216-237). Boston: McGraw-Hill. 
Ozturk, H. \& Cecen, S. (2007). The effects of portfolio keeping on writing anxiety of EFL students. Journal of Language and Linguistic Studies, 3(2), 218-236.

Phillips, E. M. (1991). Anxiety and oral competence: classroom dilemma. The French Review, 65, 114.

Phillips, E. M. (1992) The effects of language anxiety on students' oral test performance and attitudes. The Modern Language Journal, 76, 14-26.

Price , M. L. (1991) The subjective experience of foreign language anxiety: interviews with highly anxious students. In E. K. Horwitz \& D. J. Young (Eds.), Language anxiety: from theory and research to classroom implications. (pp. 101-108). Englewood Cliffs, NJ: Prentice Hall.

Saito, Y., Horwitz, E. K., \& Garza, T. J. (1999). Foreign language reading anxiety. The Modern Language Journal, 83(2), 202-218.

Saito, Y., \& Samimy, K. K. (1996) Foreign language anxiety and language performance: a study of learner anxiety in beginning, intermediate, and advanced-level college students of Japanese. Foreign Language Annals, 29, 239-251.

Samimy, K. (1994). Teaching Japanese: consideration of learners' affective variables. Theory into Practice, 33(1), 29-33.

Sarason, I. G. (1980). Introduction to the study of test anxiety. In I. G. Sarason (Ed.), Test anxiety: theory, research, and applications (pp. 3-14). Hillsdale, NJ: Lawrence Erlbaum Associates.

Sheen, Y. (2008). Recasts, language anxiety, modified output, and L2 learning. Language Learning, 58(4), 835-874.

Sieber, J. E. (1980). Defining test anxiety: problems and approaches. In I. G. Sarason (Ed.), Test anxiety: theory, research, and applications (pp. 15-40). Hillsdale, NJ: Lawrence Erlbaum Associates.

Skehan, P. (1989). Individual differences in second language learning. London, NY: Arnold.

Tsui, A. B. M. (1996). Reticence and anxiety in second language learning. In K. M. Bailey \& D. Nunan (Eds.), Voices from the language classroom: qualitative research in second language education (pp. 145-167). Cambridge: Cambridge University Press.

Vogely, A. J. (1998). Listening comprehension anxiety: students' reported sources and solutions. Foreign Language Annals, 31(1), 67-80.

Vogely, A. (1999). Addressing listening comprehension anxiety. In D. J. Young (Ed.), Affect in foreign language and second language learning: a practical guide to creating a low-anxiety classroom atmosphere (pp. 106-123). Boston: McGraw-Hill.

Watson, D., \& Friend, R. (1969). Measurement of social-evaluative anxiety. Journal of Consulting and Clinical Psychology, 33, 448-457.

Woodrow, L. (2006). Anxiety and speaking English as a second language. RELC Journal, 37(3), 308328.

Young, D. J. (1990). An investigation of students' perspectives on anxiety and speaking. Foreign Language Annals, 23(6), 539-553.

Young, D. J. (1992). Language anxiety from the foreign language specialist's perspective: interviews with Krashen, Omaggio Hadley, Terrell, and Rardin. Foreign Language Annals, 25(2), 157-172. 